\title{
Digital Right in the Field of Inheritance
}

\author{
Bessarab N.S.
}

\author{
Tula State University, Tula, Russia, \\ *Corresponding author. Email: Benata2704@bk.ru
}

\begin{abstract}
The paper analyzes the concepts and components of digital rights. The author of the paper reviewed the issue of legal regulation of digital rights in terms of the amendments made in the First, Second Part and Article 1124 of the Third Part of the Civil Code of the Russian Federation, as well as made the analysis of the main changes amendments to the Civil Code of the Russian Federation. The legalization of digital rights in the Russian civil circulation meets the needs of its development, however, unfortunately, it does not eliminate the difficulties that arise during the transfer of these rights under the procedure of inheritance. The recognition of the inheritance of digital rights still remains the problem since technical specifics of circulation of these rights complicate both the process of establishment of the ancestor's digital asset and the access of lawful heirs thereto.
\end{abstract}

Keywords: digital right, inheritance, token, digital asset, property item

\section{INTRODUCTION}

Digital technology has long been a part of our everyday lives. The market for digital objects is developing dynamically on the Internet through trading accounts, cryptocurrencies, etc.

Transactions made on the Internet are dynamically distributed around the world by pressing the OK button on a PC, smartphone, or sending a message (for example, shopping in an online store). These transactions are called "smart contracts."

The purchase of goods and services via the Internet has long been one of the main areas of the consumer market. The emergence of e-commerce and other digital capabilities makes life quite simple but due to the fact that these relations were not legalized, big risks have been formed.

Digital rights in civil law create the required legal conditions for signing contracts on the Internet and protect citizens and firms when making transactions with digital assets.

Digital rights are a new term in the Civil Code of the Russian Federation. These rights were introduced by the law "On Amendments to the First, Second Parts and Article 1124 of the Third Part of the Civil Code of the Russian Federation" No. 34-FZ dated March 18, 2019.

The purpose of the adoption of this law is the need to lay the foundation for the creation of legislation governing various relations on the application or disposal of digital assets.

\section{RESEARCH METHODOLOGY}

The methodology and research methods of this paper are the method of structural and functional analysis, the method of formal logic, including methods of analysis, synthesis, induction, and deduction, as well as special methods of legal research, i.e. comparative-law one, including methods of system analysis and interpretation of legal standards.

\section{LEGAL NATURE OF THE DIGITAL RIGHT}

Federal Law No. 34-FZ dated 18.03.2019 "On Amendments to the First, Second Parts and Article 1124 of the Third Part of the Civil Code of the Russian Federation" consolidated the term "digital right" [1]. The very first edition of this bill No. 424632-7 had a definition of the concept of the "digital asset," which was equated with property, but over time this designation was removed, having become a part of the digital right. The explanatory note to the bill said that the economic relations that were formed on the Internet, formed by developing new objects that require regulation of this area of public relations, which led to the emergence of the concept of the "digital right" in Russian law that became equal to the term "token." This means that the introduction of decentralized information systems that are based on the blockchain into the list of property objects indicates a response of the civil law sphere to socio-economic changes in life and digitalization of civil circulation, i.e. the fact that civil law objects may be in demand on the information technology market [2]. 
The emergence in the civil circulation of the digital right, which is identical to the term "token," provoked different opinions of civilian scientists regarding its content and legal nature [3].

A number of scientists believe that it is impossible to define a token as a concept that combines homogeneous components. According to A.M. Laptev, it is required to apply the "property complex" structure in relation to tokens. Such the application will lead to an indication of the features of objects with the establishment of their signs and properties, as well as the unification of the legal regime [4]. A.I. Saveliyev proposes to consider the token as a digital asset that has a specific value [5]. According to E.L. Sidorenko, the token is a digital asset, and there should be a binding relationship between the issuer and the buyer of tokens [6]. Many of the civilian scientists, among whom we may single out L. Novosyolova, A. Guznov, Ye. Avakyan, L. Mikheyeva, and others, define the term token as "a digital designation of the right to an object of law" [7] (the first edition of the bill No.424632-7 had this very this definition).

S.V. Sarbash denies the digital right, taking it as a legal fiction only. According to M.A. Rozhkov, in the case of the digital right, we may only talk about the electronic form of existing subjective civil rights [8].

A. Bychkov is of a different opinion and he notes the possibility of alienating this right and its ability to be transferred from one person to another in the manner of universal succession [9]. This is explained by the free economic value of the digital asset, which the asset has as a certified right to an object that is encrypted in the asset and which covers the powers to access the code (password, login, etc.) and to dispose of the digital asset [10].

Russian scientists understand the digital right as a legal structure that resembles a security. This understanding makes it possible to use the gaps and conflicts that refer to the legal regulation of the digital right, the analogy of the law, particularly, the rules used for securities. L.A. Novosyolova draws a parallel with the existing rules of civil law institutions and believes that it is possible to extend the legal regime of paperless securities to the digital right. According to A.I. Saveliyev, such types of law as exclusive, property, and obligation may be used [11]. Noteworthy is the position of A.G. Sergo, who is talking about adapting existing legal realities to modern digital technologies. This synthesis is possible within the boundaries of the new aggregate industry, nanolaw [12]. Therefore, the legal literature has several definitions of the digital right, among which a digital unit, a type of a digital asset, and a token.

Article 141.1 of the Civil Code of the Russian Federation compares the token with some kind of property value and in connection with this, the token can be included in the inherited property and in the bankruptcy asset when considering bankruptcy cases.

As T.S. Yatsenko notes, there are specific difficulties in the inheritance of the token, arguing that it is difficult to establish the fact that the ancestor has a digital asset and heirs have access to it. Proving his opinion, T.S. Yatsenko gives the following explanation:

- the issue of tokens is possible without observing specific formalities (exception is its issue regulated by the securities law);

- $\quad$ tokens are reflected in the registries (blockchain) and transferred without the participation of third parties [13].

The aforesaid circumstances indicate the anonymity of transfers, which lead to the fact that subjects that take part in transactions have an idea only about the object; information about the holder is unknown, its identification is impossible.

In addition, technical issues may arise, which refer to the exercise of inheritance rights, i.e persons who, due to age or some other reason (poverty, lack of interest or specific knowledge), will not have access to technical devices, and therefore, according to paragraph 2 of Article 141.1 of the Civil Code of the Russian Federation, will not be able to become owners of the digital right. In connection with the foregoing, T.S. Yatsenko believes that if the ancestor did not leave the information and access code, then from the legal position, the token is included in the hereditary mass and transferred to the heir, but from the technical one, this does not happen because the heir does not have unique access to this registry, and therefore, this automatically means that the heir does not have digital rights either.

It should be taken into account that not every token can be inherited. For example, at the moment, this is not allowed in relation to the so-called payment tokens, which perform the function of a cryptocurrency and which are used to pay for a product or service because the legislator refused to include digital money in the Russian system of civil rights. This means that there is no certainty in the components of the rights that are included in the hereditary mass since in accordance with Articles 128 and 141.1 of the Civil Code of the Russian Federation, the obligation and other property rights mentioned in this capacity in the law are recognized as digital [2].

Foreign countries have made an attempt to solve these problems. For example, in the USA, a Uniform Law on the access of fiduciary to electronic assets has been developed and the Netherlands supports the idea of notaries on the formation of a "digital repository," in which customers may store their digital data, including access codes [13]. Thus, based on the foregoing, it is possible to conclude that the issue of legal consolidation of tokens is one of the most relevant issues that are on the border of civil law and information technology. The study of the legal nature of the digital right and the consolidation of this term in the legislation require further improvement.

\section{IMPLEMENTATION OF THE DIGITAL RIGHT IN THE FIELD OF INHERITANCE}

The development of digital technologies and artificial intelligence, the regulation of the use of information and Big Data circulation are the main areas of the Russian 
economy. A comprehensive approach is provided for in the statutory regulation of relations that emerge in connection with the development of the digital economy. Within the framework of the implementation of the National Program "Digital Economy of the Russian Federation" [14], a package of amendments to the Civil Code of the Russian Federation was adopted, which came into force on 10/01/2019.

Let us dwell in more detail on these amendments.

The important amendments are as follows:

- the list of objects of civil rights is amended.

Article 128 of the Civil Code of the Russian Federation consolidates a list of property rights; "digital rights" are provided as a type of property rights.

As noted above, digital rights, in accordance with the new Article 141.1 of the Civil Code of the Russian Federation, mean the obligations and other rights mentioned in this capacity in the law, the content and conditions of the implementation of which are established in accordance with the rules of the information system that meet the criteria established by law.

Since 01/01/2020, "utilitarian digital rights," which are claim rights, have been cited as a type of digital rights.

The concept of the information system is available in Article 2 of the Federal Law "On Information, Information Technologies, and Information Protection" [15], which includes a set of information that is available in databases and that ensures its processing using information technologies and technical means, which is consistent with the concept of the ISO/IEC 2382-1 International Standard, according to which an information system includes an information processing system and the resources that are associated therewith.

Information systems include automated systems, data processing centers, help services, and search engines.

The holder of the digital right is a person who has the ability to dispose of this right.

Moreover, the implementation of digital rights, their disposal, the establishment of encumbrances, as well as other restrictions, should occur within the boundaries of the information system without the need of contacting the third party. Thus, for example, digital rights cannot be included in the number of claim rights transferred under a contract of assignment, which is concluded in writing. For the transfer of digital rights, the provisions of the sale and purchase contract can be used in accordance with the new version of paragraph 4 of Article 454 of the Civil Code of the Russian Federation.

- $\quad$ there is the possibility of a transaction, including the conclusion of a contract, the fulfillment of obligations under a transaction using electronic or other technical means, an electronic document is provided as a written form of the transaction.

Article 160 of the Civil Code of the Russian Federation defines the possibility of its commission using electronic or other technical means as the method of compliance with the written form. This means that an electronic document is equivalent to a written transaction.
The amendment is quite relevant in connection with the widespread use of digital means of personal identification and transactions in the electronic environment.

The condition for compliance with the written form of the transaction is the possibility of determining the party to the transaction (the person who expressed the will). A certain way of identifying a person can be agreed upon by the parties.

At the same time, transactions, in which it is not allowed to determine the person and establish the fact of expressing its will by using electronic or other technical means should be specifically noted in the legislation.

Thus, for example, in the new wording of paragraph 1 of Article 1124 of the Civil Code of the Russian Federation, such an exception is provided for a will, which does not allow drawing up a will using electronic or other technical means. It seems that this rule is associated with the provision of additional guarantees to establish the ancestor's will in order to eliminate possible errors and abuses in this area.

Article 309 of the Civil Code of the Russian Federation is supplemented by a new paragraph, according to which the parties to the transaction may agree on the procedure for fulfilling their obligations thereon without addressing an individual expression of will using information technologies.

Thus, this rule will simplify the execution of the conditions of individual transactions involving digital rights, smart contracts, the execution of which is carried out by a computer program in an automated mode within the framework of information systems. The conditions for such execution (for example, reaching a certain price of an asset) should be agreed upon in advance by the parties when concluding the transaction.

Amendments are introduced to paragraph 2 of Article 434 of the Civil Code fo the Russian Federation in respect of compliance with the written form of the contract. According to the new edition of the article, the written form of the contract means an individual electronic document as well. Previously, the article indicated the possibility of concluding the contract by exchanging electronic documents as a way to comply with the written form.

- $\quad$ the possibility to express a will by a participant in a meeting with whom the law associates civil and law consequences by voting using electronic or other technical means is provided.

According to the new edition of Article 181.2 of the Civil Code of the Russian Federation, absentee voting of participants in a meeting is permissible, including using electronic or other technical means, which is consistent with the concept of regulating the digital environment. Thus, rules that are similar to transactions using electronic or other technical means are consolidated.

At the same time, we believe that similar additions should be introduced to Article 50 of the Federal Law "On JointStock Companies" in relation to the holding of a general meeting of shareholders in the form of absentee voting, as well as to Article 38 of the Federal Law "On Limited 
Liability Companies" on the decision of a general meeting of participants adopted by absentee voting (by poll). To date, Article 38 of the Federal Law "On Limited Liability Companies" contains an indication of the possibility of exchanging documents by electronic communication during absentee voting by participants.

- $\quad$ additions were made regarding the conclusion of a retail sale and purchase contract through the Internet. Thus, according to Article 493 of the Civil Code of the Russian Federation, an electronic receipt is as well recognized as the confirmation of the conclusion of retail sale and purchase contract.

According to the new edition of paragraph 2 of Article 494 of the Civil Code of the Russian Federation, demonstration of samples of goods or provision of details about them, including via the Internet, is as well recognized as a public offer. These amendments are aimed at resolving the existing relations for the purchase of acquiring goods via the Internet and at additional consumer protection when proving the conclusion of a contract.

- a separate rule has been included providing for the features of a contract for the provision of information services.

The contract for the provision of information services is contained in Article 779 of the Civil Code of the Russian Federation as a type of contract for the provision of services. Moreover, Article 779 of the Civil Code of the Russian Federation contains an indication only of the active actions of the contractor to perform certain actions or to carry out activities in the provision of services for a fee.

A new Article 783.1 of the Civil Code of the Russian Federation consolidates the concept and features of a contract for the provision of information services. It also provides for the possibility of passive behavior of the parties, refraining from taking steps to disclose information to third parties for a certain period of time.

- as a consequence of the new edition of Article 160 of the Civil Code of the Russian Federation, amendments have been introduced with respect to compliance with the written form of individual contracts. i.e. nominal account contract, insurance contact.

In accordance with the new edition of Article 940 of the Civil Code of the Russian Federation, the insurance contract may now be concluded in the form of an electronic document or the exchange of electronic documents or other data, by virtue of direct instruction of the Civil Code of the Russian Federation. This amendment appears to simplify civilian traffic in the insurance industry. Thus, for example, CASCO insurance policy registration will become available without visiting an insurance company.

In addition, according to Article 860.2 of the Civil Code of the Russian Federation, the written form of the nominal account contract is considered to be complied with when drawing up one electronic document signed by the parties or exchanging electronic documents or other data.

The partially declarative nature of the amendments to the Civil Code of the Russian Federation that came into force on 10/01/2019 should be noted. The rules included in the Civil Code of the Russian Federation reflect existing relations. For example, various types of service contracts for processing or providing information are widespread, for example, the provision of a messages exchange (sending/receiving) service.

The regulatory framework proposed by the legislator for the digital environment can hardly be called complete. Particularly, one of the priority areas of the digital economy, Big Data, remains unresolved. To date, there is no statutory concept of Big Data, their place in the civil rights system is not defined, and their relationship with personal data remains unclear.

The concept of "Big User Data" was proposed to be enshrined in Bill No. 571124-7, introduced in the State Duma of the Russian Federation by the Deputy M.V. Romanov on 10/23/2018. However, the proposed bill met with objections from the participants of the Big Data Association due to the excessive regulation of Big Data circulation, similar to the regulation of personal data, which will complicate the development of the Big Data market. As a result, the bill was sent for revision.

In our opinion, changes in this area are also in demand due to emerging disputes. It is impossible to define the crisp line between Big Data or "user data" and personal data. Often, the comparison of the so-called "user data" of several Internet resources, for example, social media, allows determining a specific individual, which leads to the fact that user data becomes personal data. Data processing technologies for people from social media are widely used by banks and other organizations in assessing the creditworthiness of a borrower, while this happens not always in the interests of customers, which causes a lot of controversies. For example, banks use customer data when sending them "personal offers" of their products for advertising purposes.

\section{CONCLUSION}

Therefore, the analysis showed that there is a significant field for work in the area of statutory regulation of the digital environment.

Digital rights, in a broad sense, are a set of rights of every person to access digital media and to use computers, mobile communications, and the Internet to transmit information.

The Russian legislation interprets the concept of "digital rights" much narrower. According to the amendments to the Civil Code, which came into force in October 2019, digital rights are mandatory and other rights, the contents and conditions for the exercise of which are determined by the rules of the information system.

The inheritance of digital rights from both a legal and technical point of view is still difficult and requires many factors to be taken into account. However, individual problems can be eliminated as early as now. For example, it is possible to obtain information about the existence of digital rights from the ancestor through the learning of its 
[12] A.G. Sergo Nanopravo. On the threshold of the future. Intellectual property. Copyright and related rights. 1 (2018) 7-14

[13] T.S. Yatsenko, Inheritance of digital rights, Inheritance law, no 2, 2019

[14] National program "Digital Economy of the Russian Federation". Approved by the Minutes of the meeting of the Presidium of the Presidential Council on Strategic Development and National Projects dated June 4, no. 7, 2019, URL: https://digital.gov.ru/uploaded/files/natsionalnayaprogramma-tsifrovaya-ekonomika-rossijskojfederatsii_NcN2nOO.pdf

[15] On information, information technology and information protection ": Federal Law of July 27, 2006 N 149-FZ, Russian Newspaper, Federal Issue No. 0 (4131). July 29, 2006

[3] L.Yu. Vasilevskaya, Token as a new object of civil rights: problems of legal qualification of digital law, Actual problems of Russian law., 5 (2019) 111 - 119.

[4] A.M. Lapteva Legal regime of tokens, Civil law, 2 (2019) 29 - 32.

[5] A.I. Saveliev, E-commerce in Russia and abroad: legal regulation. 2nd ed. M .: Statute, 2016, 257 p.

[6] E.L. Sidorenko, Cryptocurrency as a subject of theft: qualification problems, Magistrate judge, 6 (2018) 20 - 22.

[7] A. Guznov, L. Mikheeva, L. Novoselova, Digital assets in the system of objects of civil rights, Law, 5 (2018) $16-30$.

[8] M.A. Rozhkova, Digital assets and virtual property: how does virtual compare with digital, Zakon.ru. 2018.13 June. URL: https://zakon.ru/blog/2018/06/13/cifrovye_aktivy_i_ virtualnoe_imuschestvo_kak_sootnositsya_virtualnoe_s _cifrovym

[9] A. Bychkov Transactions with crypto assets and their legal protection, New Accounting, 4 (2018) 100 127

[10] L.V. Sannikova, Yu.S. Kharitonova, Legal essence of new digital assets, Law, 9 (2018) 86 - 95.

[11] A.I. Savelyev, Some risks of tokenization and blockchainization of civil law relations, Law 2 (2018) $36-51$. 